Рибалко Ольга Олексіївна

викладач методики навчання математики та методики навчання інформатики в початкових класах Прилуцький гуманітарно-педагогічний коледж імені I. Я. Франка, м. Прилуки, Україна

RybalkoOlga2009@rambler.ru

\title{
СТВОРЕННЯ ТА ЗАСТОСУВАННЯ ІНТЕРАКТИВНИХ ЕЛЕКТРОННИХ ТАБЛИЦЬ НА УРОКАХ МАТЕМАТИКИ В ПОЧАТКОВИХ КЛАСАХ
}

\begin{abstract}
Анотація. Актуальність матеріалу, викладеного в статті, обумовлена проблемою забезпечення навчального процесу початкової школи електронними засобами навчання. Результатом дослідження є створений студентами коледжу під керівництвом автора статті електронний навчальний посібник «Табличне додавання і віднімання чисел у межах 10». Автором детально описано технічні характеристики запропонованого електронного навчального посібника, спроектованого засобами Adobe Flash. Завдяки особливостям даного посібника майбутній педагог отримує набагато більше можливостей для повноцінного спілкування 3 учнями в порівнянні 3 класичними таблицями та іншими демонстраційними засобами навчання.
\end{abstract}

Ключові слова: математика; початкова школа; інтерактивні таблиці; електронний посібник; Adobe Flash.

\section{1. ВСТУП}

Постановка проблеми. 3 кожним роком зростає потреба в знаходженні ефективних засобів навчання, які допоможуть підвищити якість представлення вчителем навчального матеріалу, сприятимуть зацікавленню учнів, підвищуватимуть їх мотивацію до навчання, стимулюватимуть розумову діяльність і розвиватимуть творчі здібності. Інформаційно-комунікаційні технології повинні стати не додатковим засобом у навчанні, а невід'ємною частиною цілісного навчального процесу, що підвищують його ефективність і максимально сприяють всесторонньому розвитку інтелектуальної, емоційної та особистісної сфер діяльності дітей молодшого шкільного віку [2;14;15].

Значним чинником виведення освіти на якісно новий рівень $\epsilon$ не тільки забезпечення навчальних закладів комп'ютерною технікою, але й розроблення та впровадження якісних педагогічних програмних засобів. За наявності відповідного програмного забезпечення комп'ютер позитивно впливає на відношення дитини до навчання і її здатність пізнати навколишній світ [3;4;18].

Основна освітня цінність інформаційних технологій полягає в тому, що їх використання може створити більш яскраве інтерактивне середовище навчання 3 відповідними можливостями як для вчителя, так і для учнів. Крім можливостей більш ілюстративного, наочного представлення матеріалу, ефективної перевірки знань та умінь, до переваг можна віднести різноманітність організаційних форм у роботі 3 учнями та методичних прийомів у роботі вчителя [6;25].

У початковій школі результат запам'ятовування кращий з опорою на наочний матеріал. Крім того, сприйняття учнів у цьому віці тісно пов'язане з емоціями. Увага молодших школярів підтримується яскравим, образним, наочним матеріалом, живим та емоційним викладом. Дитина звертає увагу на те, що збуджує їі почуття, інтерес. Усе, пов'язане з наочністю, яскравістю вражень, викликає сильні почуття й запам'ятовується легко й надовго. Всім відомо, що жодного уроку в початковій школі не можна провести без використання наочних засобів навчання [8;10;22]. 
У минулому столітті вчителі початкових класів багато часу витрачали на виготовлення предметної та демонстраційної наочності на паперових носіях. 3 розвитком інформаційно-комунікаційних технологій учителі почали створювати навчальні презентації, використовувати демонстраційні програмні засоби, призначені для наочного подання навчального матеріалу, візуалізації досліджуваних явищ, процесів і взаємозв'язку між об'єктами [13].

Крім того, з'явився такий засіб, як інтерактивна електронна таблиця, застосування якої покликане в наочній і доступній формі представити навчальний матеріал, який вивчається на конкретному уроці. У порівнянні із звичайними поліграфічними аналогами, інтерактивні електронні таблиці $\epsilon$ сучасним багатофункціональним засобом навчання і надають більше можливостей для організації навчального процесу. Застосування інтерактивних таблиць на уроках дозволяє вчителеві залучити учнів 3 різним рівнем підготовки до процесу засвоєння знань. Педагог отримав можливість разом з учнями аналізувати, порівнювати, узагальнювати, повертатися до незрозумілих моментів або одночасно користуватися декількома об'єктами наочності.

Мета статті. Дослідити один 3 варіантів розв'язання проблеми унаочнення навчального процесу початкової школи шляхом проектування інтерактивних електронних таблиць 3 математики для початкової школи з використанням системи Adobe Flash на прикладі створеного електронного ресурсу «Табличне додавання i віднімання чисел у межах 10». Перевірити ефективність використання студентами запропонованого програмного засобу на уроках математики під час проходження педагогічної практики.

\section{2. МЕТОДИ ДОСЛІДЖЕННЯ}

Серед методів дослідження були використані теоретичні (аналіз, порівняння й узагальнення наукових положень психолого-педагогічної літератури вітчизняних i зарубіжних авторів, у тому числі електронних видань, інтернет-ресурсів і нормативної документації) й емпіричні (цілеспрямоване педагогічне спостереження за суб'єктами навчання).

\section{3. РЕЗУЛЬТАТИ ДОСЛІДЖЕННЯ}

\section{1. Проектування електронних навчальних таблиць засобами системи Adobe Flash}

У наш час вчителі молодших класів уміють створювати електронні освітні ресурси в програмі Microsoft Office PowerPoint. Студенти Прилуцького гуманітарнопедагогічного коледжу ім. І. Я. Франка грунтовно дослідили можливості проектування електронних освітніх ресурсів засобами Microsoft Office Word, Microsoft Office PowerPoint, Microsoft Office Excel. Використовуючи електронний навчальний посібник «Інформаційно-комунікаційні технології на уроках математики в початкових класах» (автор Рибалко О. О.), студенти коледжу створювали електронні освітні ресурси та перевіряли їх ефективність під час проведення пробних уроків. Стали переможцями VI, VII та лауреатами VIII Всеукраїнських конкурсів Вчитель-новатор [23;24].

Незважаючи на популярність офісних програм, педагог-розробник зустрічається 3 великою кількістю обмежень. Для створення якісних електронних освітніх ресурсів потрібно використовувати мову програмування Visual Basic for Application [1]. 
Майбутні вчителі звернули увагу на те, що майже всі електронні освітні ресурси українських розробників для початкової школи виконані в середовищі Adobe Flash. Студенти коледжу почали проектувати електронні освітні ресурси для уроків математики в початкових класах засобами Adobe Flash, використовуючи навчальний посібник «Розробка електронних освітніх ресурсів за допомогою flash-технологій» (автор Рибалко О. О.), порівняли можливості електронних освітніх ресурсів, створених в офісних програмах та в середовищі Adobe Flash за наступними критеріями: загальними показниками якості ЕОР, дидактичними показниками, ергономічними показниками [8;19]. На рис. 1 наведено приклад одного з результатів анкетування студентів, який надає змогу порівняти можливості проектування електронних інтерактивних таблиць для уроків математики засобами Adobe Flash, Microsoft Office PowerPoint тa Microsoft Office Excel.

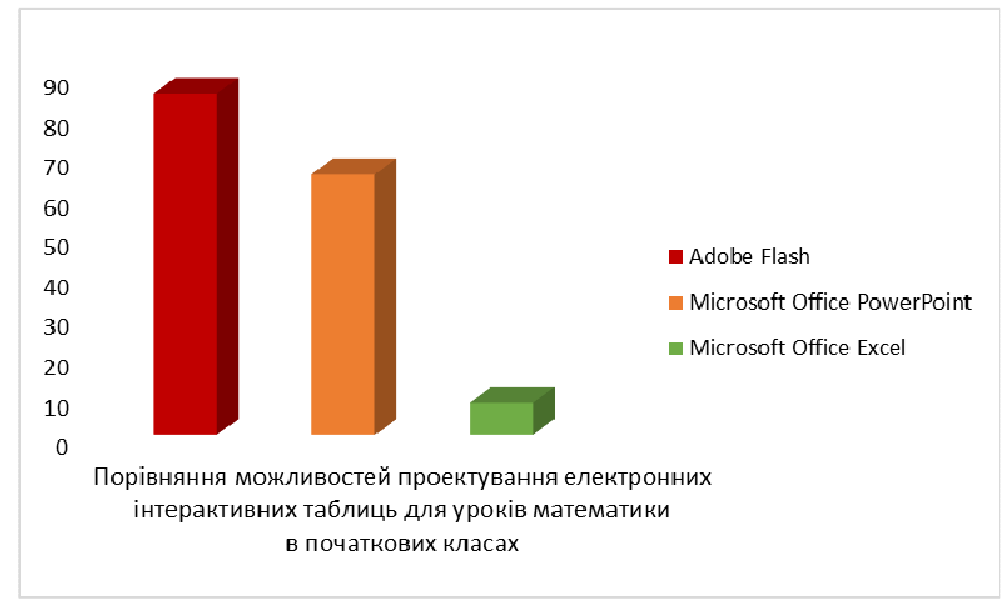

Рис. 1. Порівняння можливостей проектування електронних інтерактивних таблиць для уроків математики в початкових класах засобами Adobe Flash, Microsoft Office PowerPoint ma Microsoft Office Excel.

Студенти коледжу прийшли до висновку, що майбутньому вчителеві початкових класів потрібно навчитися працювати в Adobe Flash.

Технологія Adobe Flash, призначена для створення інтерактивного змісту i мультимедіа, $є$ могутнім редактором векторної графіки з численними можливостями, що дозволяє створювати 2D векторну графіку й анімацію, використовувати графічні зображення, а також підключити звук і відео [7;17]. Головне надбання Flash - власна мова програмування Action Script. За допомогою цієї мови можна керувати будь-яким елементом програмного продукту і змінювати його властивості [16]. У результаті застосування мови програмування Action Script вчитель має набагато більше можливостей для створення цікавого і якісного електронного ресурсу. В програмі Adobe Flash можна створювати електронні навчальні посібники, складовою яких $\epsilon$ інтерактивні таблиці й наочність, навчальні комп'ютерні моделі, дидактичні компютерні ігри та завдання, які сприяють формуванню логічного й алгоритмічного мислення, завдання для контролю знань учнів [20;21].

Електронні освітні ресурси покликані задовольнити вимоги наочності навчання не тільки на основі використання таблиць, але й за рахунок включення в їх змістовне наповнення предметної наочності, аплікацій і схематичних рисунків. Такі засоби використовуються як для виявлення істотних ознак, зв'язків, явищ, подій, процесів, так і для формування локального образного представлення навчального матеріалу. Слід пам'ятати, що електронні освітні ресурси повинні відповідати таким дидактичним 
вимогам, як науковість, доступність, наочність, самостійність, системність, послідовність, міцність засвоєння знань, єдність освітніх, розвиваючих і виховних функцій навчання, можливість вибору темпу навчання, варіативність навчання, інтерактивність навчання, корекція дій, розвиток інтелектуального потенціалу $[5 ; 11 ; 12]$.

\section{2. Електронний навчальний посібник «Табличне додавання і віднімання в межах 10»}

Більшість інтерактивних таблиць мають однакову структуру (рис. 1, рис. 2).

Від класичних таблиць інтерактивні таблиці відрізняються тим, що в них наявні кнопки, які забезпечують видимість навчального матеріалу та здатні зробити цей матеріал невидимим. Вчитель може закрити або ж відкрити записи, коли це йому потрібно. Крім кнопок повинні бути створені інтерактивні зображення, що підпорядковані як натисненню лівої кнопки миші на відповідні кнопки, так i натисненню на самі зображення (рис. 2 - рис. 3)

Під час проведення пробних уроків студенти коледжу прийшли до висновку, що найбільше вчителям початкових класів потрібні демонстраційні засоби навчання. Це спонукало їх до створення електронного навчального посібника «Табличне додавання i віднімання в межах 10». У 2015 році відбулась презентація цього посібника на VII Міжнародному фестивалі педагогічних інновацій, і студенти стали переможцями цього фестивалю.

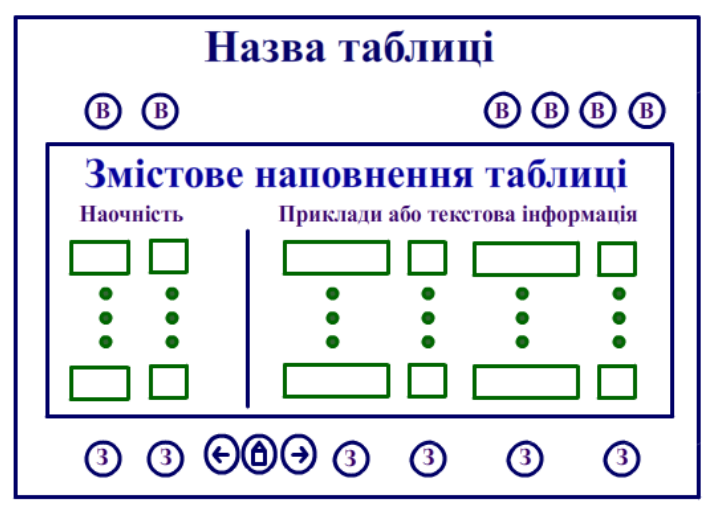

Рис. 2. Схематичне зображення структури електронної сторінки інтерактивної таблиці

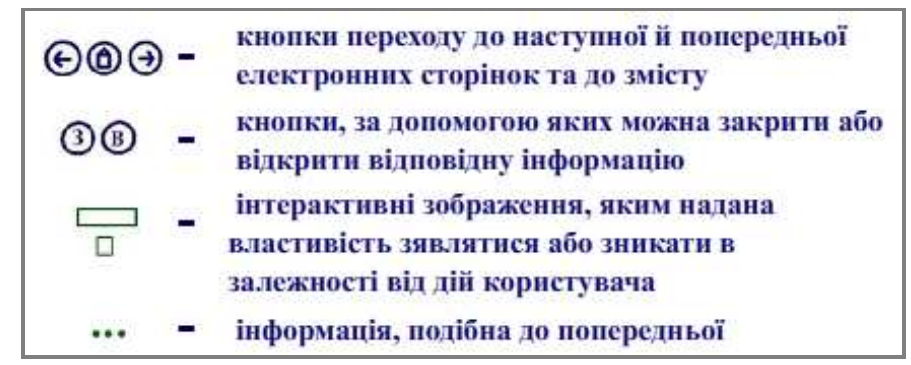

Рис. 3. Кнопки навігації електронної сторінки

Розглянемо можливості електронного навчального посібника «Табличне додавання і віднімання чисел у межах 10». Посібник призначений для використання студентами вищих педагогічних навчальних закладів та вчителями початкових класів 
під час проведення уроків математики в початковій школі і покликаний сприяти кращому засвоєнню учнями початкових класів табличних випадків додавання i віднімання чисел у межах 10. Цей програмний засіб створено в програмі Adobe Flash CS3 Professional відповідно до чинної навчальної програми 3 математики для початкової школи.

Електронний навчальний посібник «Табличне додавання і віднімання в межах 10» складається з титульної електронної сторінки (рис. 4) та електронних таблиць (рис. 5 рис. 7).

На титульній електронній сторінці $є$ перелік електронних таблиць, які може використовувати педагог, натиснувши лівою кнопкою миші на відповідному написі. У нижній частині таблиці розташовані зображення зі знаками запитання. При наведенні миші на кожен з них з`являється підказка, яку інформацію можна отримати, якщо натиснути лівою кнопкою миші на цей знак. Вчитель або студент вищого навчального закладу може познайомитись 3 інструкцією, дізнатись про використані ресурси та авторів даного ресурсу (рис. 3).

Вчителю обов`язково слід ознайомитись 3 інструкцією. Адже на цій електронній сторінці детально описано, як слід користуватись електронним посібником. За бажанням можна ознайомитись з використаними ресурсами та дізнатись, хто працював над створенням електронного ресурсу.

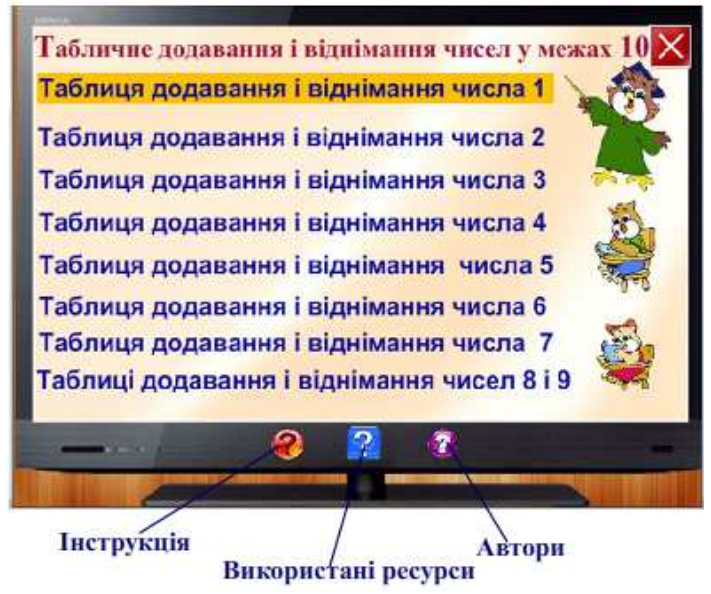

Рис. 4. Титульна електронна сторінка електронного навчального посібника «Табличне додавання і віднімання чисел у межах 10»

Обравши один з написів, вчитель переходить до вивчення відповідної таблиці додавання та віднімання. Для прикладу оберемо тему «Таблиця додавання і віднімання числа 1» (рис. 4, рис. 5). Відкривається таблиця, яка нічим не відрізняється від класичної. Але внизу та вгорі електронної сторінки розташовані кнопки жовтого кольору. За їх допомогою можна зробити всі зображення та записи видимими або невидимими. Для того, щоб учитель міг закрити всі записи, передбачені кнопки жовтого кольору розташовані внизу електронної сторінки. За допомогою цих кнопок педагог може закрити записи відповідного стовпчика (рис. 5). А за допомогою кнопок жовтого кольору, розташованих у верхній частині посібника (під заголовком таблиці), вчитель може відкрити записи відповідного стовпчика. Всіх стовпчиків шість і кнопок відповідно теж по шість. 

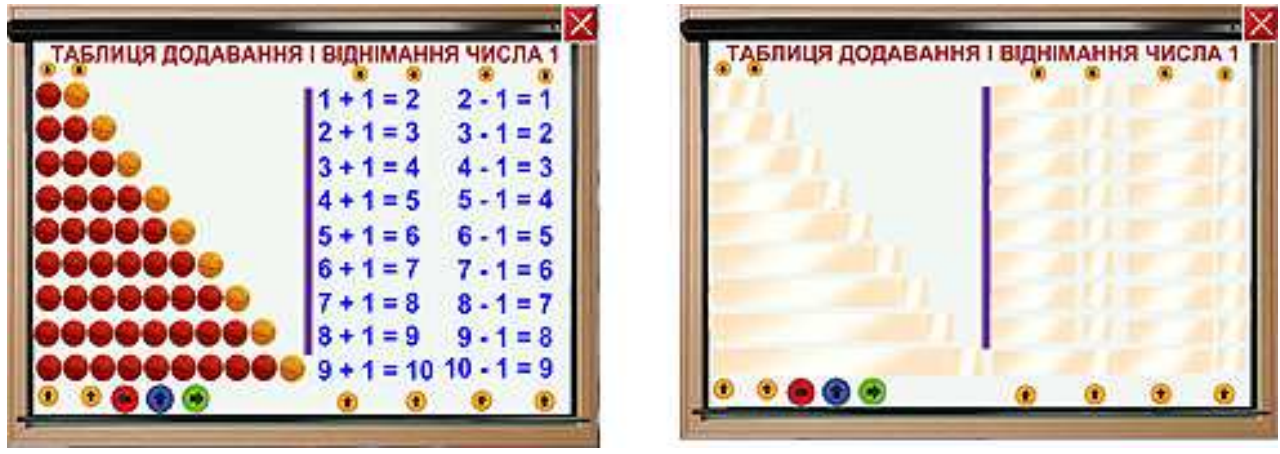

Рис. 5. Зображення електронної сторінки «Таблиия додавання і віднімання числа 1» 3 відкритими та закритими записами

Крім того, знизу електронної сторінки розташовані кнопки синього, червоного та зеленого кольорів. Це кнопки навігації. За їх допомогою можна перейти до наступної електронної сторінки (кнопка зеленого кольору), попередньої (кнопка червоного кольору) та титульної електронної сторінки (кнопка синього кольору). Цими кнопками зручно користуватись, коли педагогу потрібно швидко переходити між електронними сторінками посібника (від етапу актуалізації до вивчення нового матеріалу).

При натисненні лівої кнопки миші на зображенні кожного з м`ячів помаранчевого кольору, розташованих на рисунку по одному в кожному рядку, вони по черзі зникають. Якщо ж натиснути на їх зображенні ще раз, то м'ячі знову з'являються. Таким чином, учитель має більше можливостей під час роботи з наочністю.

Натискаючи на прямокутні зображення, вчитель поступово «відкриває» записи лише після того, як учні дадуть відповідь на поставлене ним запитання. Перевага інтерактивної таблиці над класичною полягає в тому, що вчитель має набагато більше можливостей для спілкування 3 учнями. Нарешті педагог отримав можливість самостійно вирішувати, коли учневі слід побачити той чи інший запис.

Спочатку вчитель за підтримки учнів складає таблицю додавання числа 1. Методика роботи над складанням таблиці додавання числа 1 полягає в тому, що вчитель поступово «додає» по одному м`ячу в кожному рядку, а першокласники складають відповідні приклади на додавання числа 1 (рис. 6). Вчитель працює з учнями у такий спосіб до тих пір, поки не буде складено таблицю додавання числа 1.

Методика роботи над складанням таблиці віднімання дещо інша. Педагог «закриває» всі записи, отримані в попередньому випадку. Відкриває наочність та поступово «забирає» по одному м'ячу, а молодші школярі складають відповідні приклади на віднімання числа 1 (рис. 6).
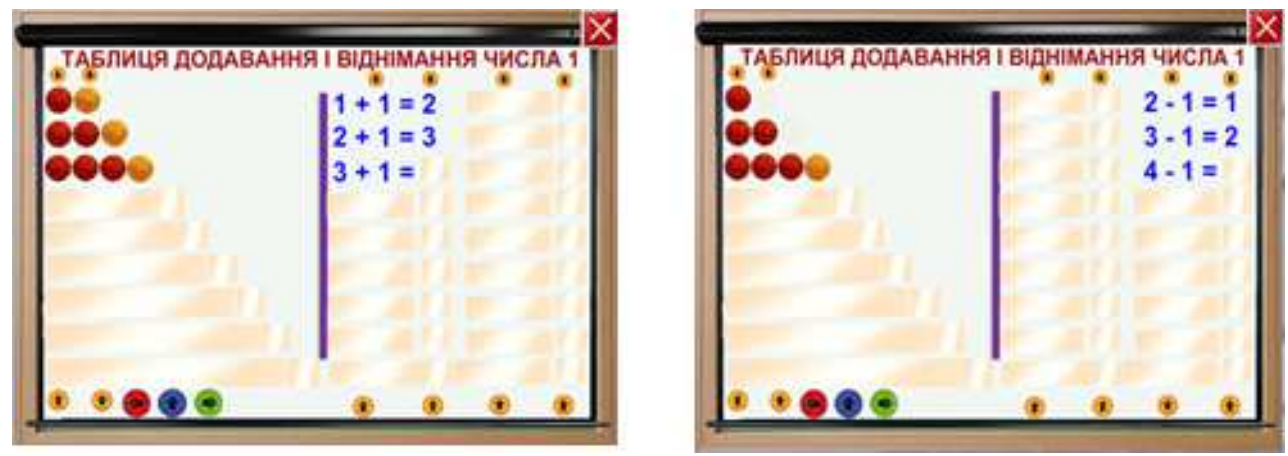

Рис. 6. Зображення електронної сторінки в процесі засвоєння учнями таблиці додавання числа 1та таблииі віднімання числа 1 
За методикою, описаною вище, можна проводити роботу на етапі вивчення нового матеріалу. А на етапі закріплення наочність не потрібно використовувати. Учні відповідають на поставлені запитання, а вчитель має змогу поступово відкривати завдання та відповіді.

У такий спосіб проводиться робота з усіма електронними таблицями, які входять до складу цього електронного посібника (рис.7).
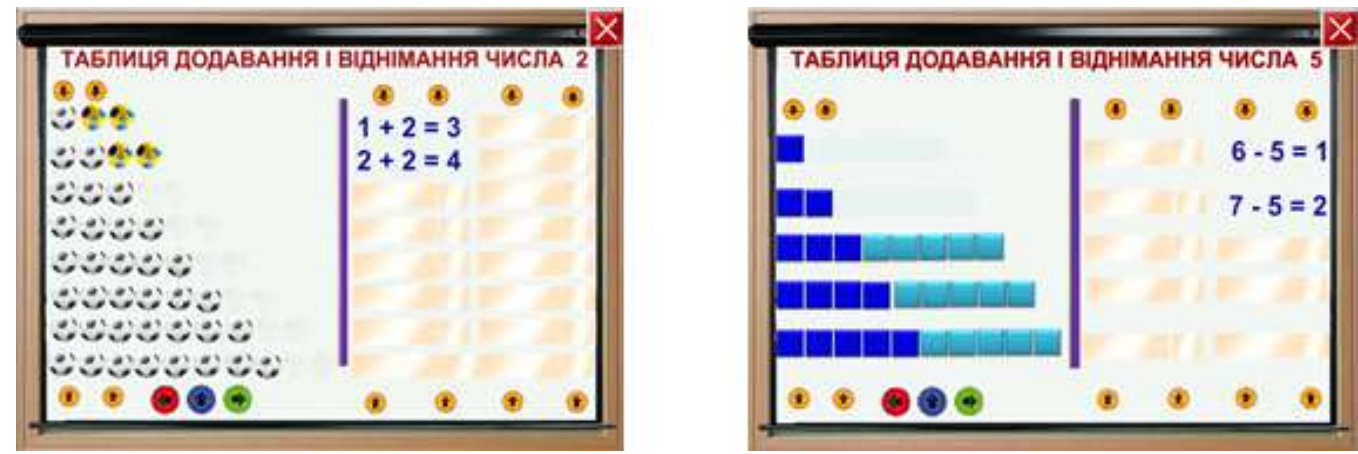

Рис. 7. Робота з таблииями «Додавання і віднімання числа 2» та «Додавання $i$ віднімання числа 5» на етапі вивчення нового матеріалу відповідних тем

Електронний навчальний посібник «Таблиця додавання і віднімання в межах 10» виконаний у форматі, який допускає систему навігації, що дає можливість вчителеві вільно переміщатися сторінками електронного посібника. Електронний посібник можна встановити на будь-яку модель комп'ютера: звичайний стаціонарний персональний комп'ютер, ноутбук, нетбук або планшет. Він є дидактичним засобом, який можна використовувати на різних етапах навчання: 3 метою засвоєння нових знань, закріплення і вдосконалення знань, умінь і навичок, а також перевірки і корекції навчальних досягнень учнів. Це сприяє інтенсифікації праці як педагога, так і учня.

Даний посібник зручно використовувати як складову презентації до уроку. Презентація дає можливість скомпонувати навчальний матеріал, виходячи 3 особливостей конкретного класу та теми уроку математики в початкових класах, дозволяє побудувати урок так, щоб досягнути найбільшого навчального ефекту, подання максимального об'єму інформації, наочності й естетичності. Використовування комп'ютерних презентацій структуру уроку принципово не змінюють. Для того, щоб використати електронний навчальний посібник, потрібно у визначеному місці презентації створити гіперопосилання на посібник та зберігати його разом з презентацією.

\section{4. ВИСНОВКИ ТА ПЕРСПЕКТИВА ПОДАЛЬШИХ ДОСЛІДЖЕНЬ}

Студенти Прилуцького гуманітарно-педагогічного коледжу мали змогу використовувати електронний посібник під час проведення пробних уроків 3 математики протягом двох місяців у першому класі та переконатися в ефективності використання цього програмного засобу на уроках математики в початковій школі. Майбутні вчителі пересвідчились, що матеріал посібника є доступним для сприймання учнями початкових класів і використання його сприяє покращенню навчального процесу, дозволяє не тільки поліпшити якість навчання, але й підвищити пізнавальний інтерес учнів першого класу. Застосування інтерактивних електронних таблиць допомагає майбутньому вчителю формувати в учнів початкових класів позитивні 
мотиви до навчання, розвивати творчі здібності, сприяе активізації розумової діяльності першокласників.

Використання інтерактивних електронних таблиць на уроках математики в початковій школі дозволяє майбутнім педагогам спостерігати за динамікою засвоєння учнями навчального матеріалу. Застосування інтерактивних електронних таблиць 3 дозованим змістом і покроковим алгоритмом засвоєння знань доповнює навчальний процес додатковими можливостями. Використання інтерактивних електронних таблиць на уроках математики в початкових класах допомагає реалізувати індивідуальний підхід до освітньої траєкторії кожного учня, акцентувати увагу саме на тих питаннях, що найгірше засвоюються учнями певного класу.

Перспективним напрямком подальших досліджень $\epsilon$ навчання студентів коледжу проектуванню електронних освітніх ресурсів для навчання математики в початковій школі, які повинні виконувати одночасно функції комп'ютерної підтримки теоретичного компоненту змісту навчання і розвитку розумових здібностей учнів молодших класів.

\section{СПИСОК ВИКОРИСТАНИХ ДЖЕРЕЛ}

1. Авдеева Е. В. Создание электронного интерактивного плаката / Е. В. Авдеева // Информатика и образование 2010. №12. С. $84-85$.

2. Биков В. Ю. Сучасні завдання інформатизації освіти [Електронний ресурс] / В. Ю. Биков // Інформаційні технології і засоби навчання. - 2010. - №1 (15).- Режим доступу : http://journal.iitta.gov.ua/index.php/itlt/article/view/25

3. Белоусова Л. И. Дидактический потенциал цифровых образовательных ресурсов для младших школьников [Электронный ресурс] / Л. И. Белоусова, Н. В. Олефиренко // Образовательные технологии и общество. - 2013. - №1(16). - Режим доступу: http://cyberleninka.ru/article/n/didakticheskiy-potentsial-tsifrovyh-obrazovatelnyh-resursov-dlyamladshih-shkolnikov

4. Вембер В. П. Інформатизація освіти та проблеми впровадження педагогічних програмних засобів у навчальний процес [Електронний ресурс] / В. П. Вембер // Інформаційні технології і засоби $\begin{array}{lllllll}\text { навчання. } & -2007 . & - & № 2 & \text { (3). }\end{array}$ http://journal.iitta.gov.ua/index.php/ittl/article/view/262\#.VQ-PdBrPJ88

5. Дем'яненко В. М. Шляхи забезпечення якості програмних засобів навчального призначення / В. М. Дем'яненко, М. П. Шишкіна //Комп'ютер у школі та сім'ї. - 2010. - №5. - С. 50-53.

6. Денисенко В. В. Теоретико-методичні засади використання інформаційних технологій підготовки майбутніх учителів початкової школи / В. В. Денисенко // Інформаційні технології в освіті. - 2013. - № 16. С. $63-67$.

7. Думиньш А. А. Компьютерные игры в обучении и технологии их разработки [Электронный ресурс] / А. А. Думиньш, Л. В. Зайцева // Образовательные технологии и общество. - 2012. №3(15). - Режим доступа: http://cyberleninka.ru/article/n/kompyuternye-igry-v-obuchenii-i-tehnologiiih-razrabotki

8. Жугастрова О. В. Дидактичні показники оцінки якості програмних засобів навчального призначення [Електронний ресурс ] / О.В. Жугастрова // Інформаційні технології і засоби навчання. $\quad-\quad 2011.2 \quad-\quad № 1$ (21). Режим доступу: http://journal.iitta.gov.ua/index.php/itlt/article/view/346/366

9. Клюєва Т.М. Реалізація принципу наочності на уроках у початковій школі засобами інформаційних технологій навчання [Електронний ресурс] / Т. М. Клюєва // Таврійський вісник освіти. - 2013. - №3 (43). С. 10 - 16. Режим доступу: http://nbuv.gov.ua/j-pdf/Tvo_2013_3_4.pdf

10. Лаврентьєва Г. П. Психолого-педагогічні аспекти використання ІКТ в початковій школі [Електронний ресурс] / Г. П. Лаврентєва // Інформаційні технології і засоби навчання. - 2012. - №3 (29). - Режим доступу: http://journal.iitta.gov.ua/index.php/ittl/article/view/675/511\#.VlqzP2wY3_Q

11. Лаврентьєва Г. П. Методичні рекомендації з оцінювання психолого-педагогічних характеристик якості електронних освітніх ресурсів [Електронний ресурс] / Г. П. Лаврентьєва // Інформаційні технології і засоби навчання. - 2014, №3 (41). - Режим доступу: http://j2.iitta.gov.ua/index.php/ittl/article/view/1048/796 
12. Литвинова С. Г. До питання експертизи якості електронних освітніх ресурсів [Електронний ресурс] / С. Г. Литвинова // Інформаційні технології і засоби навчання. - 2013. - №34(2) - Режим доступу: http://journal.iitta.gov.ua/index.php/itlt/article/view/812\#.VeqFn0Pg21t

13. Лобода Ю. Г. Електронні засоби навчання: структура, зміст, класифікація / Ю.Г. Лобода // Інформаційні технології і засоби навчання. - 2012. - №2 (28). - Режим доступу до журналу: http://journal.iitta.gov.ua/index.php/itlt/article/view/649/492

14. Машбиц Е.И. Психолого-педагогические проблемы компьютерного обучения / Е. И. Машбиц // M. 1988. - 167c.

15. Мельник О. М. Розвиток електронних освітніх ресурсів для організації навчально-виховного процесу в системі початкової освіти / О. М. Мельник // Початкова школа. - 2015. - №5. - С. 40 44.

16. Мук Коллин. Action Script 3.0 для Flash / Коллин Мук // - П: Питер, 2009. - 987 с.

17. Огнівчук Л. М. Використання flash-технологій і јаva-аплетів в електронному навчальному курсі 3 елементарної математики [Електронний ресурс] / Л. М. Огнівчук //Інформаційні технології і засоби навчання. -2015. $\quad-\quad$ №4 $\quad$ (48). http://journal.iitta.gov.ua/index.php/itlt/article/view/1249

18. Олефиренко Н. В. Проблемы подготовки учителя начальной школы к проектированию дидактических электронных ресурсов [Электронный ресурс]/ Н. В. Олефиренко // Образовательные технологии и общество. - 2014. - №1(17). - Режим доступа: http://cyberleninka.ru/article/n/problemy-podgotovki-uchitelya-nachalnoy-shkoly-k-proektirovaniyudidakticheskih-elektronnyh-resursov

19. Оцінювання якості програмних засобів навчального призначення для загальноосвітніх навчальних закладів : монографія / [Жалдак М. І., Шишкіна М. П., Лапінський В. В., Скрипка К. І. та ін.]; за наук. ред. проф. М. І. Жалдака. - К. : Педагогічна думка, 2012. - 132 с.

20. Пушкарьова Т. О. Електронний навчальний посібник з математики для учнів початкових класів / Т. О. Пушкарьова, О. О. Рибалко// Комп’ютер у школі та сім’ї. - 2012. - № 5. - С.16 -21.

21. Пушкарьова Т. О., Рибалко О. О. Електронний навчальний посібник з математики для 1 класу / Т. О. Пушкарьова, О. О. Рибалко // Комп’ютер у школі та сім’ї. - 2014. -№ 2. - С.43 - 46.

22. Рибалко О. О. Молодший школяр і комп`ютер / О. О. Рибалко// // Комп’ютер у школі та сім’ї. 2010. - №5. -C.21 - 24 .

23. Рибалко О.О. Використання майбутніми педагогами інформаційно-комунікаційних технологій у навчанні молодших школярів / О. О. Рибалко // Вища освіта України №3 (додаток 1). - 2011р. Т.2. - C.501 - 508 .

24. Рибалко О. О. Участь студентів коледжу у проектній діяльності / О. О. Рибалко // - Комп’ютер у школі та сім’ї. - 2011. - №8. - С. 25 - 29.

25. Савченко 3. В. Формування і використання інформаційних електронних науково-освітніх ресурсів [Електронний ресурс] / 3. В. Савченко //нформаційні технології і засоби навчання. - 2010. - №4 (18). - Режим доступу до журналу : http://journal.iitta.gov.ua/index.php/itlt/article/view/316/295

Матеріал надійшов до редакиії 29.02.2016 p.

\title{
СОЗДАНИЕ И ПРИМЕНЕНИЕ ИНТЕРАКТИВНЫХ ЭЛЕКТРОННЫХ ТАБЛИЦ НА УРОКАХ МАТЕМАТИКИ В НАЧАЛЬНЫХ КЛАССАХ
}

\author{
Рыбалко Ольга Алексеевна \\ преподаватель методики обучения математике и методики обучения информатике в начальных классах \\ Прилукский гуманитарно-педагогический колледж имени И. Я. Франко, г. Прилуки, Украина \\ RybalkoOlga2009@rambler.ru
}

\begin{abstract}
Аннотация. Актуальность материала, изложенного в статье, обусловлена проблемой обеспечения учебного процесса начальной школы электронными средствами обучения. Результатом исследования является созданное студентами колледжа под руководством автора статьи электронное учебное пособие «Табличное сложение и вычитание чисел в пределах 10». Автор описывает возможности данного электронного учебного пособия, спроектированного средствами Adobe Flash. Благодаря техническим характеристикам данного пособия педагог получает намного больше возможностей для полноценного общения с учениками во время использования данного программного средства в сравнении с классическими таблицами и другими демонстрационными средствами обучения.
\end{abstract}


Ключевые слова: математика; начальная школа; интерактивные таблицы; электронное пособие; Adobe Flash.

\title{
THE CREATION AND USE OF INTERACTIVE SPREADSHEETS ON LESSONS OF MATHEMATICS IN PRIMARY SCHOOL
}

\author{
Olha O. Rybalko \\ Teacher in teaching methods of mathematics and informatics in primary school \\ Humanitarian Pedagogical College, Pryluky, Ukraine \\ RybalkoOlga2009@rambler.ru
}

\begin{abstract}
Relevance of the material presented in the article is due to the problem of provision of primary school educational process by electronic teaching aids. As the result of the research is the guidance of electronic textbook "Tabular adding and subtracting numbers within 10" established by college students directed by the author. The author describes in detail the possibilities of the electronic textbook, designed by Adobe Flash means. Due to the specifications of this manual a teacher gets more opportunities to fully communication with students while using this software product in comparison with classic demonstration tables and other teaching aids.
\end{abstract}

Keywords: mathematics; primary school; interactive tables; electronic guide; Adobe Flash.

\section{REFERENCES (TRANSLATED AND TRANSLITERATED)}

1. Avdeeva E. V. Create interactive electronic poster / E. V. Avdeeva // Information and education. 2010. №12. C. 84 - 85. (in Russian)

2. Bykov V. U. Modern tasks of informatics education [online] / Bykov V. U. // Information technologies and learning tools. - 2010. - №1 (15). - Available from: http://journal.iitta.gov.ua/index.php/itlt/article/view/25 (in Ukrainian).

3. Belousova L. I. Didactic potential of digital educational resources for pupil [online] / L. I. Belousova, N. V. Olefirenko // Educational Technology \& Society. - 2013. - №1(16). - Available from: http://cyberleninka.ru/article/n/didakticheskiy-potentsial-tsifrovyh-obrazovatelnyh-resursov-dlyamladshih-shkolnikov (in Russian)

4. Vember V. P. Informatization of education and problems of implementation of educational software in educational process [online]/ V. P .Vember // Educational Technology \& Society. - 2007. - №2 (3). Available from: http://journal.iitta.gov.ua/index.php/itlt/article/view/262\#.VQ-PdBrPJ88 (in Ukrainian)

5. Demyanenko V. M. Ways of providing quality educational software / Demyanenko V. M., Shishkina M. P. //Computer in family and school. - 2010. - №5. - C. 50 -53. (in Ukrainian).

6. Denysenko V. V. Theoretical and methodological foundations of information technology training of primary school teachers / V. V. Denysenko // Information Technologies in Education. - 2013. - № 16. C. 63 - 67. (in Ukrainian)

7. Duminsh A. A. Computer games in learning and technology development [online] / A. A. Duminsh, L. V. Zayceva // Educational Technology \& Society. - 2012. - №3(15). - Available from: http://cyberleninka.ru/article/n/kompyuternye-igry-v-obuchenii-i-tehnologii-ih-razrabotki (in Russian)

8. Djugastrova O. V. Educational indicators for assessing the quality of educational software [online] / Djugastrova O. V. // Information technology and learning tools. - 2011. - №1 (21). - Available from: http://journal.iitta.gov.ua/index.php/itlt/article/view/346/366 (in Ukrainian).

9. Klyeva T.M. The principle of clarity in the classroom in elementary school by means of information technology education [online] / N. M. Klyeva // Taurian Journal of Education - 2013. - №3 (43). C. 10 16.

Available from: http://nbuv.gov.ua/j-pdf/Tvo_2013_3_4.pdf (in Ukrainian)

10. Lavrentyeva G. P. Psychological and pedagogical aspects of using ICT in primary school [online] / G. P. Lavrentyeva // Information technology and learning tools. - 2012. - №3 (29). - Available from http://journal.iitta.gov.ua/index.php/itlt/article/view/675/511\#.VlqzP2wY3_Q (in Ukrainian)

11. Lavrentyeva G. P. Guidelines for evaluation of psychological and pedagogical quality characteristics of electronic educational resources [online] / G. P. Lavrentyeva // Information technology and learning tools. - 2014, №3 (41). - Available from

http://j2.iitta.gov.ua/index.php/itlt/article/view/1048/796 (in Ukrainian)

12. Litvinova S. G. On the issue of quality examination of electronic educational resources [online] / S. G. 
Litvinova // Information technology and learning tools. - 2013. - № 34(2). - Available from: http://journal.iitta.gov.ua/index.php/itlt/article/view/812\#.VeqFn0Pg21t (in Ukrainian)

13. Loboda U. G. Electronic education tools: structure, content, classification / Loboda U. G // Innformation technology and learning tools. - 2012. - №2 (28). - Available from: http://journal.iitta.gov.ua/index.php/itlt/article/view/649/492 (in Ukrainian).

14. Mashbicz E.I. Psycho-pedagogical problems of computer-based training / E.I. Mashbicz // - M. 1988. 167c. (in Russian)

15. Melnyk O. M. (2015). The development of electronic educational resources to the educational process in primary education. Primary School, 5, 40 - 44. (in Ukrainian).

16. Mock Kollin. ActionScript 3.0 for Flash / Mock Kollin // - П. 2009. - 987 c. (in Russian)

17. Ognivchyk L. M. Using of Flash technology and java applets in electronic education curse of mathematics[Electronic resource] /Ognivchyk L. M.//nformation technology and learning tools. - 2015. №4 (48). - Available from : http://journal.iitta.gov.ua/index.php/itlt/article/view/1249 (in Ukrainian).

18. Olefirenko N. V. Problems of training primary school teachers to design teaching electronic resources / N. V Olefirenko // Educational Technology \& Society. - 2014. - №1(17). - Available from: http://cyberleninka.ru/article/n/problemy-podgotovki-uchitelya-nachalnoy-shkoly-k-proektirovaniyudidakticheskih-elektronnyh-resursov (in Russian)

19. Evaluation the quality of educational software for secondary schools: monograph / [Jaldak M. I., Shishkina M. P., Lapinskiy V. V., Skripka K. I. And others]; According to science redactor of Jaldak M. I. - K. :Pedagogical thought, 2012. - 132 c. (in Ukrainian).

20. Pushkaryova T. O. The electronic textbook on mathematics for primary school pupils / T. O. Pushkaryova, O. O. Rybalko // The computer at school and family. - 2012. - № 5. - C.16-21. (in Ukrainian).

21. Pushkaryova T. O., Rybalko O. O. The electronic textbook on mathematics for Form1 /T. O. Pushkaryova, O. O. Rybalko // The computer at school and family. - 2014. -№ 2. - C.43 - 46. (in Ukrainian)

22. Rybalko O. O Junior student and computer / O. O. Rybalko // The computer at school and family. -2010. - №5. -C.21 - 24. (in Ukrainian)

23. Rybalko O. O The use of the future teachers of ICT in teaching younger pupils / O. O. Rybalko // Higher education Ukraine №3 (annex 1) - 2011. - T.2. - C.501-508. (in Ukrainian)

24. Rybalko O. O. The participation of college students in the project activity / O. O. Rybalko // The computer in the school and the family.- 2011. - №8. -C.25-29. (in Ukrainian)

25. Savchenko Z. V. Formation and usage of electronic information science and educational resources [online] / Savchenko Z. V. //Information technology and learning tools. - 2010. - №4 (18). - Available from: http://journal.iitta.gov.ua/index.php/itlt/article/view/316/295 (in Ukrainian).

Conflict of interest. The author has declared no conflict of interest.

\section{$(\mathrm{Cc}) \mathrm{BY}-\mathrm{NC}-\mathrm{SA}$}

This work is licensed under Creative Commons Attribution-NonCommercial-ShareAlike 4.0 International License. 